\title{
Feasibility of personalized primary prevention (PPP) in osteoporotic fracture management
}

\author{
Istvan Marton
}

From EPMA-World Congress 2013

Brussels, Belgium. 20-21 September 2013

Age related chronic health conditions generate sever socio-economic problems in the developed countries, especially in the EU [1]. The significance and feasibility of prevention became evident, but no sound information was available to demonstrate the effectiveness of these measures [2]. Most programs running have short duration. An osteoporosis prevention program was initiated more than 20 years ago in Hungary and follow up information became accessible by now. National wide statistical figures gave solid evidence of the feasibility of PPP.
The only country within the European Union was Hungary, where - with our active ontribution - a 20 years prevention campaign to reduce osteoporotic fractures and Social security expenses - resulted in an approved positive outcome, indicated by the decreasing overall hip fracture incidence, and related expenses despite of the increased number of over 60 years age population and extended life expectancy (1990-2012) and inflation [3]. All those measures, including beneficial effects of vitamin $\mathrm{D}$, are presented here. Data supported evidences of the

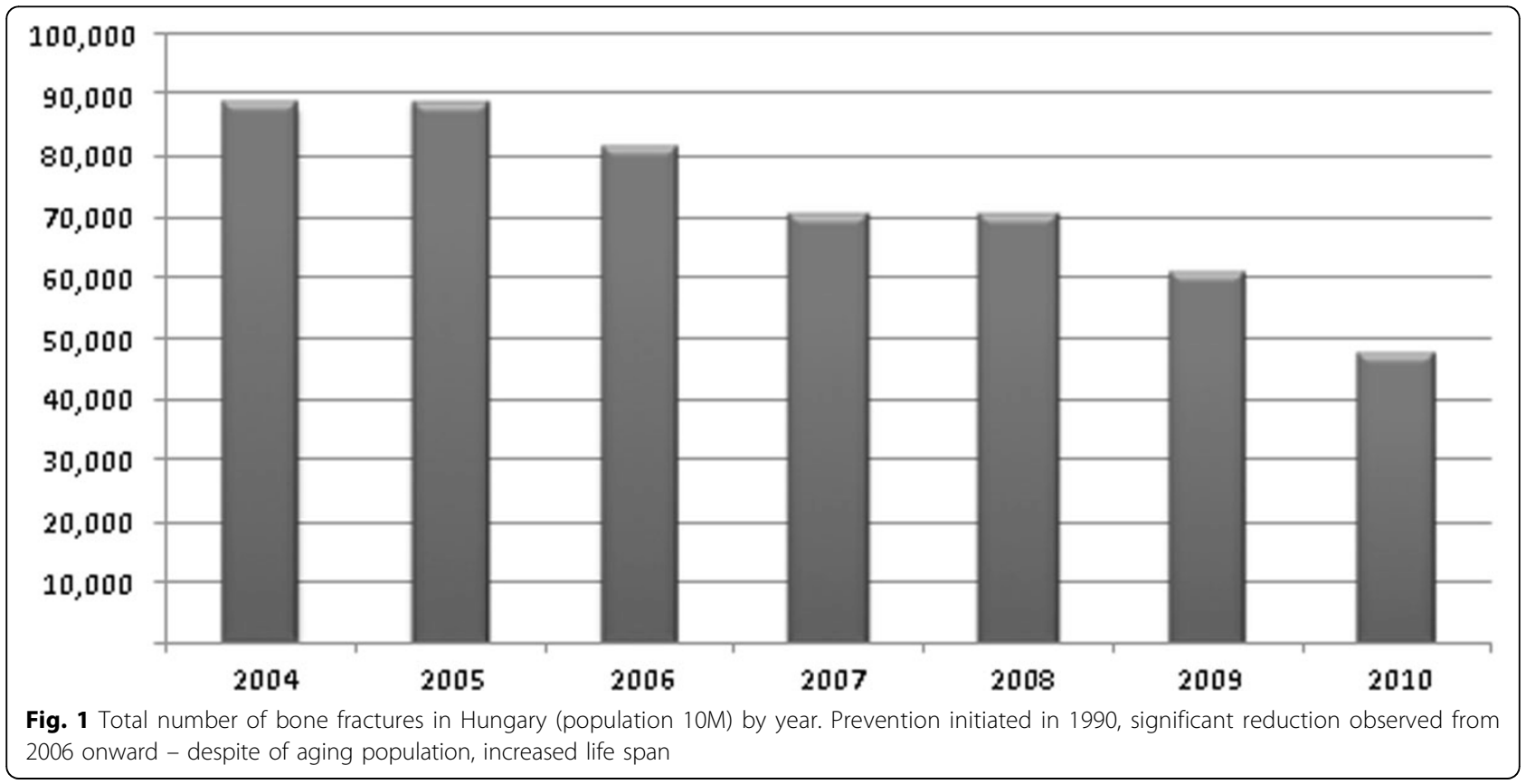

Correspondence: imartondr@aol.com

Quintess, Budapest, Hungary 


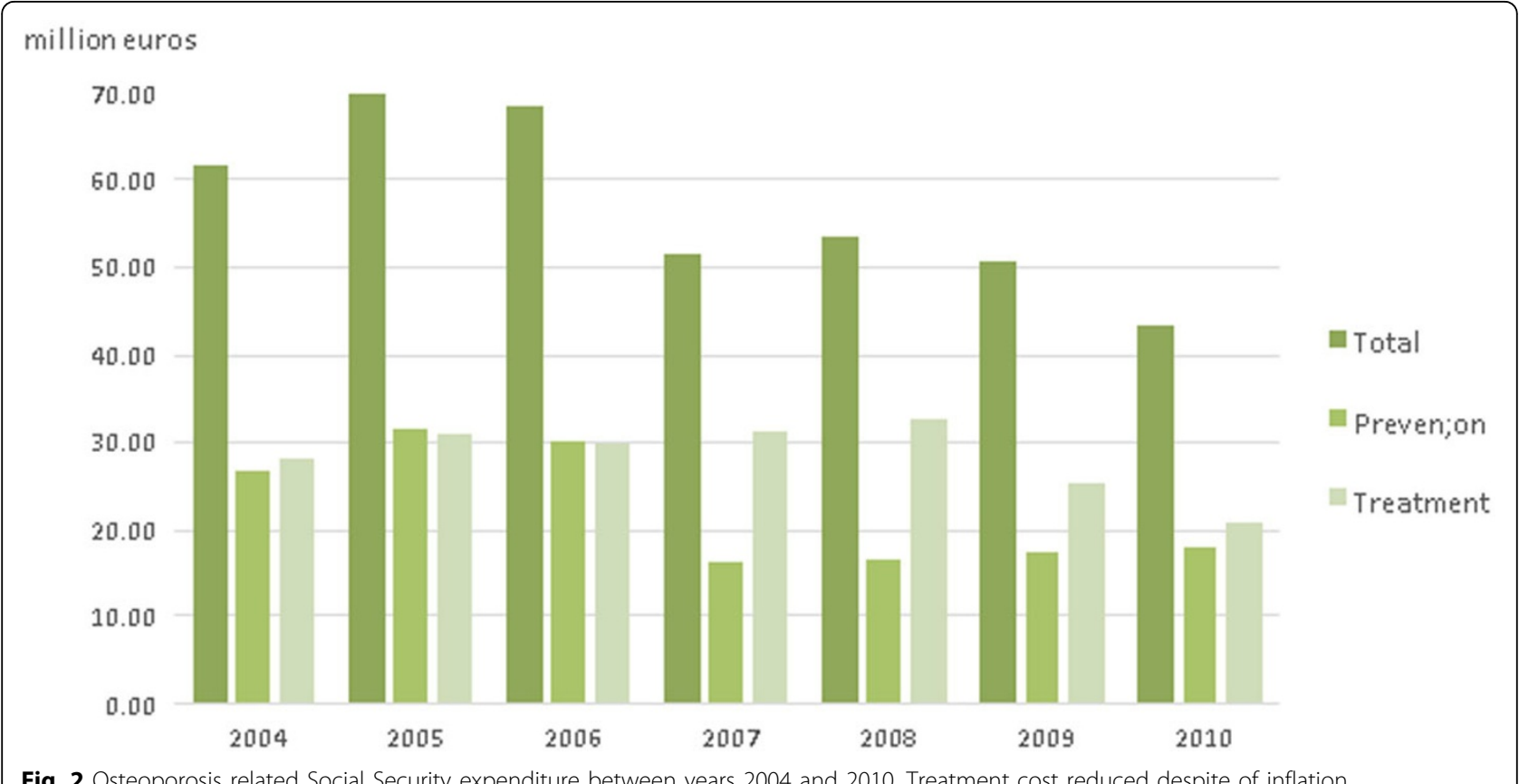

significance of centralized data collection, and education of specialist working on integrative medical approach.

Published: 11 February 2014

\section{References}

1. Cummings SR, Melton LJ: Epidemiology and outcomes of osteoporotic fractures. Lancet 2002, 359(9319):1761-1767.

2. ORGANIZATION WHO: Reducing Risks Promoting Healthy Life. The WORLD HEALTH REPORT 2002.

3. Lakatos P, Tóth E, Szekeres L, Poór G, Héjj G, Takács I: A csontritkulás kezelésének hatékonysága Magyarországon - OEP adatelemzés. LAM KID 2012, 2:5-12.

doi:10.1186/1878-5085-5-S1-A150

Cite this article as: Marton: Feasibility of personalized primary

prevention (PPP) in osteoporotic fracture management. EPMA Journal 2014 5(Suppl 1):A150

\section{Submit your next manuscript to BioMed Central} and take full advantage of:

- Convenient online submission

- Thorough peer review

- No space constraints or color figure charges

- Immediate publication on acceptance

- Inclusion in PubMed, CAS, Scopus and Google Scholar

- Research which is freely available for redistribution

Submit your manuscript at www.biomedcentral.com/submit
C Biomed Central 